\author{
Military Technical College \\ Kobry Elkobbah, Cairo, \\ Egypt.
}

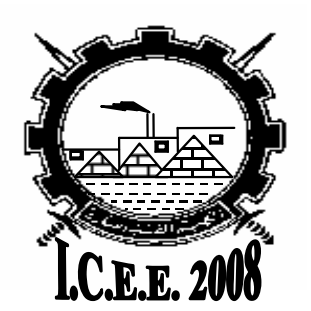

$4^{\text {th }}$ International Conference On Chemical \& Environmental Engineering

27-29 May 2008

\title{
ADVANCED PROPELLING SOLUTIONS COMPLING WITH FUTURE DEMANDS (FCS)
}

\author{
MOHAMED SAMMOUR*
}

\section{ABSTRACT}

During the last decade, requirements on ammunition and and their components have changed considerably. New emphases are laid in the fields of safety, vulnerability and toxicity / environmental impact. Most conventional introduced gun propellants originate from the WWII era and show considerable shortcomings in particular regarding these new requirements.

The new requirement for propellants: i) increased performance, ii) reduced system weight at same performance, iii) low price (cheap), iv) reduced toxicity I environmental impact (green propellant), v) reduced sensitiveness IM / LOVA (less sensitive propellant), and vi) good system compatibility (ignitability, barrel erosion, muzzle flash,...).

Three examples for the new propellants were presented: i) example 1: new artillery propellants, ii) Example 2: new tank gun propellants, and example 3: new small caliber propellants.

Thanks to decades of intensive R\&D, a variety of propellants with improved properties were developed, many of them being already NATO qualified and in service.

\footnotetext{
* Ministry of military production, F81
} 